\title{
RELATION OF DIRECT FOREIGN INVESTMENTS AND ECONOMIC GROWTH: PANEL DATA ANALYSIS ON APEC COUNTRIES
}

\author{
DOI: 10.17261/Pressacademia.2018.935 \\ JEFA- V.5-ISS.3-2018(4)-p.261-267

\section{Nazife Ozge Kilic ${ }^{1}$, Ilhan Gullu'} \\ ${ }^{1}$ Agri Ibrahim Cecen University, Agri, Turkey. \\ nokilic@agri.edu.tr, ORCID: 0000-0002-6738-3638 \\ ${ }^{2}$ Nevsehir University, Nevsehir, Turkey. \\ igullu@hotmail.com, ORCID: 0000-0003-4467-4579
}

Date Received: August 2, 2018

Date Accepted: September 19, 2018

To cite this document

Kilic, N. O., Gullu, I. (2018). Relation of direct foreign investments and economic growth: panel data analysis on APEC countries. Journal of Economics, Finance and Accounting (JEFA), V.5(3), p.261-267.

Permemant link to this document: http://doi.org/10.17261/Pressacademia.2018.935

Copyright: Published by PressAcademia and limited licenced re-use rights only.

\section{ABSTRACT}

Purpose- In this study, relation between direct foreign investments and economic growth had been analyzed for 11 APEC countries (Australia, Canada, Chile, China, Indonesia, Japan, Korea, Malaysia, Mexico, Russia and USA) in between era of 1990-2016 with the help of panel data analysis.

Methodology- In this purpose, stability of variables had been searched by Im,Peseran and Shin Panel Unit Root Tests, Maddala and Wu Panel Unit Root Tests and Coi Panel Unit Root Tests to obtain unbiased predictions in study. Then, panel cointegration and causality tests had been applied.

Findings- At the end of the research, it had been determined that existence of causality relation between series and there is unidirectional causality from direct foreign investments to economic growth.

Conclusion- Although direct foreign investment in most of the developing countries is not directly linked to economic development, capital, technology and knowledge transfer which indirectly contributes. For this reason, developing countries are encouraging foreign direct investment.

Keywords: Direct foreign investments, economic growth, APEC countries, panel data analysis. JEL Codes: E20, O16, O40.

\section{INTRODUCTION}

Asia-Pacific Economic Cooperation had been established for moving forward of economic development and wealth level and for strengthen of connection between Asia Pacific Community in 1989. APEC has 21 members. APEC members have corresponded to $40 \%$ of world population, $56 \%$ of world GDP and approximately $48 \%$ of world trading volume. Basic aims of cooperation in the scope of APEC is to decrease tariffs among members and reduce other trade barriers, to make contribution for formation of efficient economies in local basis and increase export significantly thanks to this (www.apec.org, 2018).

With increase in economic integration movements, studies that examines the effects of economic integrations on member countries and countries staying out of integration had started to increase in economic literature. Effects of economic integrations has mainly divided into two as static effects and dynamic effects. While static effects are referred to "trade creation" and "trade diversion" effects which are for once only; dynamic effects have defined the more long-termed effects of economic integrations. One of the most important dynamic effects of economic integrations is the promotion effect for foreign investments and especially for the direct foreign investments (DFI). Economic integration has caused to gather of production in unity in more effective hands and drawing significant foreign capital investment to the region by enlarging market volume by liberalizing the trade among member countries (Çeştepe and Mıstaçoğlu, 2010:94). 
Besides that, DFI is a special external financing in terms of developing countries and contribution to formation of capital, it has more importantly ensured the access to market network as much as transferring of technology, innovation capacity and executive abilities. However, it cannot say that international capital trend shows a proper distribution among developing countries. Economic and politic other factors have played a role in that as much as DFI drawing capacities.

In literature, it has been seen that large majority of studies that examines the effect of economic growth on direct foreign investments in economic integrations are made on regional integrations among developed countries as EU. In this study, relation between direct foreign investments and economic growths have been discussed for APEC Countries. While, in second chapter following the introduction of study, it had been given place to empirical studies that examines the relation between direct foreign investments and economic growth, in last chapter, effect of direct foreign investments on economic growth had been tested by econometric modelling in 11 chosen APEC Countries.

\section{LITERATURE REVIEW}

In international growth literature, the effect of direct foreign investments on growth have been one of frequently searched subjects. In empirical literature, a lot of studies that are done on single country as well as on countries are available for relation between direct foreign investments and economic growth. The existence positive relation had been found between related variables which are used in the most of the studies that investigate the relations between direct foreign investments and economic growth. It has been coincided at least to negative and meaningless relation between direct foreign investments and economic growth in literature. Studies examining the relation between direct foreign investment and economic growth had been divided into two as studies which are made in Turkey and international studies.

Table 1: National Studies Investigating the Relationship between Foreign Direct Investment and Economic Growth

\begin{tabular}{|c|c|c|c|}
\hline Author (s) & Period & Method & Results \\
\hline Yapraklı (2006) & 1970-2006 & $\begin{array}{l}\text { Multiple } \begin{array}{r}\text { Cointegration } \\
\text { and Error Correction } \\
\text { Model }\end{array} \\
\end{array}$ & DYY $\neq$ Growth \\
\hline Afşar (2007) & 1992:1 2006:3 & Granger Causality & FDI $\rightarrow$ Growth \\
\hline Karagöz (2007) & 1970-2005 & $\begin{array}{l}\text { Johansen Cointegration, } \\
\text { ECM Granger Causality }\end{array}$ & DYY $\neq$ Employment \\
\hline Ayaydın (2010) & 1970-2007 & $\begin{array}{l}\text { Cointegration, Granger } \\
\text { Causality }\end{array}$ & FDI $\rightarrow$ Growth \\
\hline Ekinci (2011) & $1980-2010$ & Engle-Granger Causality & FDI $\leftrightarrow$ Growth \\
\hline Koyuncu (2011) & $1990-2010$ & Granger Causality & FDI $\leftrightarrow$ Growth \\
\hline Yılmaz vd. (2011) & $1980-2008$ & EG Cointegration & Positive effect \\
\hline Şahin (2015) & $1980-2013$ & ARDL Bounds Test & Positive effect \\
\hline Işıı (2016) & $1970-2014$ & ARDL Bounds Test & FDI $\leftrightarrow$ Growth \\
\hline $\begin{array}{l}\text { Kahveci and Terzi } \\
(2017)\end{array}$ & 1984-2015 & $\begin{array}{l}\text { Sims and DL-VAR } \\
\text { Causality }\end{array}$ & Growth $\rightarrow$ FDI \\
\hline
\end{tabular}

Yapraklı (2006), Karagöz (2007), Ayaydın (2010), Yılmaz et al. (2011) investigated whether there is a long-term relationship between FDI and growth using the cointegration method. While Ayaydın and Yılmaz have not found any relationship between economic growth and direct foreign investments, Yılmaz has found that there was a positive relationship between economic growth and foreign direct investment. Afşar (2007), Ekinci (2011), Koyuncu (2011) found that there is a causal relationship between foreign direct investment and economic growth in the studies on causality relationship between foreign direct investment and economic growth.

Table 1 has consisted of empirical studies that are made to show the effect of direct foreign investments on economic growth in Turkey. There is unidirectional or bidirectional causality relation between direct foreign investments and economic growth in the 8 of 10 studies which are given in Table 1 . Any causality relation had not been discovered in the remaining 2 studies. 
Table 2: International Studies Investigating the Relationship between Foreign Direct Investment and Economic Growth

\begin{tabular}{|c|c|c|c|c|}
\hline Author (s) & Period & Countries & Method & Results \\
\hline $\begin{array}{l}\text { Blomstorm, Lipsey } \\
\text { and Zejan (1992) }\end{array}$ & $1960-1985$ & $\begin{array}{l}78 \text { Developing } \\
\text { Country }\end{array}$ & $\begin{array}{l}\text { Granger } \\
\text { Causality Test }\end{array}$ & FDI $\neq$ Growth \\
\hline Zhang (2001) & 1984-1998 & China Zones & $\begin{array}{ll}\begin{array}{l}\text { Panel data } \\
\text { analysis }\end{array} & \\
\end{array}$ & FDI $\rightarrow$ Growth \\
\hline $\begin{array}{l}\text { Kholdy and } \\
\text { Sohrabian (2005) }\end{array}$ & $1975-2002$ & 25 Countries & Granger Causality & FDI $\neq$ Growth \\
\hline $\begin{array}{l}\text { Carcovic and Levine } \\
(2002)\end{array}$ & $1960-1995$ & 72 Countries & $\begin{array}{l}\text { Panel } \\
\text { analysis }\end{array}$ & FDI $\neq$ Growth \\
\hline $\begin{array}{l}\text { Alfaro and Charlton } \\
(2007)\end{array}$ & $1990-2001$ & 22 OECD Countries & $\begin{array}{ll}\begin{array}{l}\text { Panel } \\
\text { analysis }\end{array} & \text { data } \\
\end{array}$ & $\begin{array}{l}\text { A positive and } \\
\text { meaningful relationship }\end{array}$ \\
\hline $\begin{array}{l}\text { Okuyan and Erbaykal } \\
(2007)\end{array}$ & $1970-2006$ & $\begin{array}{l}9 \quad \text { Developing } \\
\text { Country }\end{array}$ & $\begin{array}{l}\text { Toda-Yamamoto } \\
\text { Causality }\end{array}$ & FDI $\leftrightarrow$ Growth \\
\hline Shaikh (2010) & 1981-1999 & $\begin{array}{l}47 \quad \text { Developing } \\
\text { Country }\end{array}$ & $\begin{array}{l}\text { Panel data } \\
\text { analysis }\end{array}$ & Negative effect \\
\hline $\begin{array}{l}\text { Sichei and Kinyondo } \\
(2012)\end{array}$ & $1980-2009$ & $\begin{array}{ll}45 & \text { African } \\
\text { Countries } & \end{array}$ & $\begin{array}{ll}\begin{array}{l}\text { Panel } \\
\text { analysis }\end{array} & \text { data } \\
\end{array}$ & Positive effect \\
\hline $\begin{array}{l}\text { Wang and Wong } \\
(2009)\end{array}$ & 1970-1989 & 69 Countries & $\begin{array}{l}\text { Panel data } \\
\text { analysis, Dynamic } \\
\text { SUR }\end{array}$ & FDI $\rightarrow$ Growth \\
\hline
\end{tabular}

In Table 2, it had been given place to studies that examine the direct foreign investments and economic growth in the world. While relation has not been found in three of nine studies, negative relation had been found in one study. In the remaining 5 studies, positive and meaningful results had showed up between direct foreign investments and economic growth in the remaining 5 studies.

In the majority of international studies examining the relationship between economic growth and foreign direct investment, there was no causal relationship between economic growth and foreign direct investment. Blomstorm, Lipsey and Zejan (1992), Kholdy and Sohrabian (2005), Carcovic and Levine (2002) and Shaikh (2010) used causality analyzes and they have not found any relationship between economic growth and foreign direct investment.

\section{RESEARCH METHOD}

\subsection{Search Period and Data Set}

In the study, relation between direct foreign investments and economic growth had been tried to examine in 11 APEC Countries ${ }^{1}$ by using annual data related to era of 1990-2016. 11 APEC countries had been taken in application in terms of accessibility to variables used in research. GDP variable which are used as dependent variable to represent the economic growth have shown growth rate as percentage of GDP by years. Direct foreign investments and capital variables which are used in analysis had been taken as independent variable. The model to be estimated is as follows:

$G D P_{i t}=6_{i t}+f d i_{i t}+c a p_{i t}+e_{i t}$

Panel data analysis that has many superiorities against other technics had been preferred in the study. The most important specification of panel data analysis is allowing to constitute data set which has time dimension as well as section dimension by gathering time series and cross-sectional series.

Panel unit root tests had been firstly applied to get unbiased predictions for model (1) which is defined in study. In this context, since stability status of variables in panel data analyzes was applied to methodology which will be used in models, it had been firstly gone to that stability towards variables which are used in models is examined by Im, Peseran and Shin Panel Unit Root Tetst, Maddala and Wu Panel Unit Root Tests and Coi Panel Unit Root Tests and stability conditions of variables is determined. Then, at the end of the unit root tests, Cointegration Test had been applied to analyze the possible long-term relation between variables which are used in models that all variables are in same level and stable in their first differences.

\footnotetext{
${ }^{1}$ Australia, Canada, Chile, China, Indonesia, Japan, Korea, Malaysia, Mexico, Russia, USA
} 


\subsection{Panel Unit Root Tests}

Panel unit root tests that are frequently used in literature are Levin and others (2002), Im, Pesaran and Shin (2003) and, Maddala and Wu (1999). Panel unit root tests have given information one by one about which are stable or not for series constituting the panel. At analysis stage of search, Im, Peseran and Shin (2003), Maddala and Wu (1999) and Choi (2001) Panel Root Tests which are from panel root tests had been used.

Test statistic which is developed by $\mathrm{Im}$, Peseran and shin (2003) is as below:

$\Delta y_{i t}=\alpha_{i} y_{i t-1}+\sum_{j=1}^{\rho_{i}} \gamma_{i j} y_{i t-j}+X_{i t}^{\prime} \delta+\varepsilon_{i t}$

$\Delta y_{i t}=y_{i t}-y_{i, t-1}$

$y_{i t}(i=1,2, \ldots \ldots \ldots, n ; t=1,2, \ldots \ldots . . T)$

Unit root hypotheses are given below:

Ho: $\alpha_{i}=0$ : Series is not stationary. $\mathrm{H}_{\mathrm{A}}: \alpha_{i}<0$ : Series is stationary.

Maddala and Wu (1999) had developed a Fisher type test that combines probability values from unit root tests for each cross section. Test is without parameter and has $2 n$ degree of freedom ( $n$ has shown the number of countries in panel). Test statistic has been shown as:

$\lambda=-2 \sum_{i=1}^{n} \log _{e}\left(p_{i}\right) \sim x_{2 n(\text { d.f. })}^{2}$

Choi (2006), derives another test statistic.

$Z=\frac{1}{\sqrt{n}} \sum_{i-1}^{n} \phi^{-1}\left(p_{i}\right) \sim N(0,1)$

$\phi^{-1}$; is the inverse of the normal cumulative distribution function.

\section{Table 3: Im, Peseran, Shin Panel Unit Root Test}

\begin{tabular}{|l|l|l|}
\hline Level & W-Statistic & Probability \\
\hline Variables & -6.6613 & $0.0000^{* * *}$ \\
\hline GDP & -3.7626 & $0.0001^{* * *}$ \\
\hline Fdi & -7.4158 & $0.0000^{* * *}$ \\
\hline Cap &
\end{tabular}

Note: ${ }^{*}, * * * *$ represent $10 \%, 5 \%, 1 \%$ significance levels

Table 4: Maddala and Wu Unit Root Test

\begin{tabular}{|l|c|c|}
\hline \multicolumn{2}{|l|}{ Level } & \multicolumn{1}{|l|}{} \\
\hline Variables & ADF Fisher Statistic & Probability \\
\hline GDP & 83.1446 & $0.0000^{* * *}$ \\
\hline Fdi & 47.2589 & 0.0005 \\
\hline Cap & 92.9810 & 0.0000 \\
\hline
\end{tabular}

Note: $*, * *, * * *$ represent $10 \%, 5 \%, 1 \%$ significance levels

Table 5: Choi Panel Unit Root Test

\begin{tabular}{|l|l|l|}
\hline \multicolumn{2}{|c|}{ Level } & \multicolumn{1}{|c|}{} \\
\hline Variables & Z-Statistic & Probability \\
\hline Fdi & -6.4371 & $0.0000^{* * *}$ \\
\hline Cap & -3.9098 & $0.0000^{* * *}$ \\
\hline
\end{tabular}

Note: ${ }^{*}, * *, * * *$ represent $10 \%, 5 \%, 1 \%$ significance levels 


\subsection{Panel Cointegration Test}

At the result of panel unit root tests, cointegration analysis which is established on the assumption that all series are integrated from first degree has been applied to analyze whether there is long term relation between variables or not by using Johansen Fisher Panel Cointegration test. Johansen Fisher panel cointegration tests is panel version of individual Johansen cointegration test. Johansen Fisher panel cointegration test has based on total of $p$-values of trace statistics and individual Johansen maximum eigenvalue. Also, $\mathrm{p}$ value which is obtained from individual cointegration test for $p_{i}$ section ' $\mathrm{i}$ ' under null hypothesis, test statistics for panel is as follows:

$-2 \sum_{i=1}^{n} \log \left(p_{i}\right) \sim X_{2 n}^{2}$

Cointegration test results in Johansen type panel had depended on delay number of VAR system (Hossain, 2011:6995).

Kao (1999) cointegration test has based on below panel regression model.

$y_{i t}=x_{i t}^{\prime} \beta+z_{i t}^{\prime} \gamma+\varepsilon_{i t}$

In number (9) equality, it has been assumed that $y_{i t}$ and $x_{i t}$ is stable in I(1) level and a cointegrated relation does not happen. Kao (1999) that defends a equality as $z_{i t}=\left\{\mu_{i t}\right\}$ had analyzed the cointegration relation between series with reference to DF and ADF unit root tests which will be done for $\varepsilon_{i t}$ series (Lau et al., 2011:148).

Table 6: Lag Length Test Results

\begin{tabular}{|l|l|l|l|l|l|l|}
\hline Lag Lenght Criteria & LogL & LR & FEP & AIC & SC & HQ \\
\hline 0 & -1982.125 & NA & 3068.911 & 16.54271 & 16.58622 & 16.56024 \\
\hline 1 & -1866.398 & 227.5969 & 1261.042 & 15.65332 & 15.82735 & 15.72344 \\
\hline 2 & -1840.713 & 49.87198 & 1097.391 & 15.51427 & $15.81883^{*}$ & 15.63699 \\
\hline 3 & -1830.766 & $19.06535^{*}$ & $1088.867^{*}$ & $15.50638^{*}$ & 15.94116 & 15.68169 \\
\hline
\end{tabular}

Note: LR: Likelihood Ratio Test, FPE: Last Forecast Error, AIC: Akaike Information Criteria, SC: Schwarz Information Criteria HQ: Hannan Quinn Information Criteria. * sign indicates the most appropriate delay length determined according to the relevant criteria.

Table 7: Panel Cointegration Test

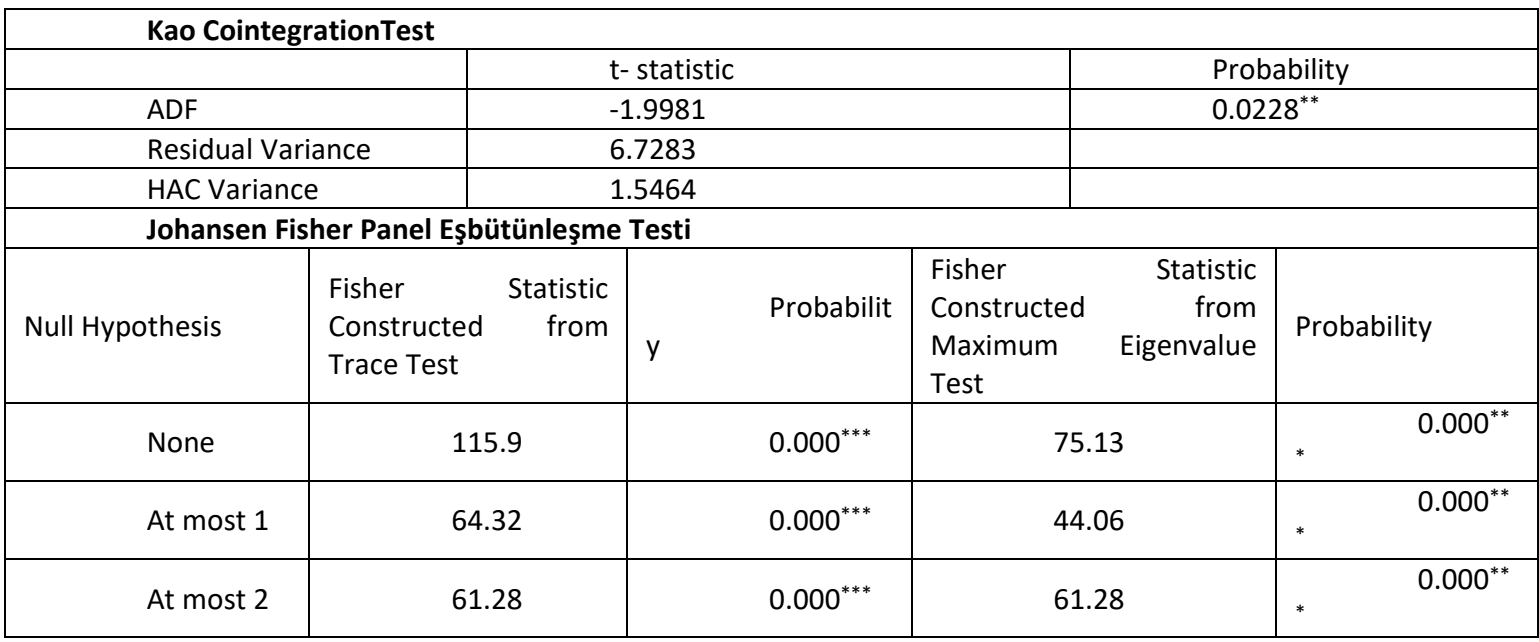

Note: ${ }^{* *}, * *, *$ indicate that the null hypothesis is rejected at the significance level of $1 \%, 5 \%$ and $10 \%$, respectively. In Kao cointegration test, Barlett Kernel method was used and Bandwith width was determined by Newey-West method.

\subsection{Panel Causality Test}

Whether there is causality relation between RD expenses and patent numbers or not had been analyzed by panel which Granger causality method which is developed by Dumitrescu and Hurlin (2012). Dumitrescu and Hurlin (2012) panel Granger causality test is a method which is brought in to literature lately. In terms of an economic fact, due to high probability of that causality relation which is effective for a country is also effective for other countries, causality relation 
has been tested more effectively with more observations in mentioned causality test within the frame of panel data. In Dumitrescu-Hurlin panel Granger causality test, lack of homogeneous Granger causality relation under basic hypothesis is tested against the alternative hypothesis which this relation exists in at least cross section (Bozoklu and Yılancı, 2013:175).

Table 8: Dumitrescu-Hurlin Panel Causality Test Results

\begin{tabular}{|c|l|l|l|}
\hline Null Hypothesis & W-Stat & Zbar Stat & Probability \\
\hline cap $\rightarrow$ GDP & 3.16 & 1.201 & 0.229 \\
\hline GDP $\rightarrow$ cap & 5.07 & 3.636 & $0.000^{* * *}$ \\
\hline fdi $\rightarrow$ GDP & 3.93 & 2.176 & $0.029^{* *}$ \\
\hline GDP $\rightarrow$ fdi & 3.21 & 1.268 & 0.204 \\
\hline fdi $\rightarrow$ cap & 3.99 & 2.256 & $0.024^{* *}$ \\
\hline cap $\rightarrow$ fdi & 5.14 & 3.720 & $0.000^{* * *}$ \\
\hline
\end{tabular}

Note: ${ }^{*}, * *, * * *$ represent $10 \%, 5 \%, 1 \%$ significance levels

Panel causality test results have been shown in table 6 . In the research that economic growth, direct foreign investments and causality relation between capital variables were searched, unidirectional causality had been determined from direct foreign investments to economic growth.

\section{CONCLUSION AND DISCUSSIONS}

One of the economic politics which is important in implementation way of growth and developments of developing countries is direct foreign investments. Direct foreign investments have importance in terms of making deep of capital accumulation, developing export and increasing of technology transfer.

As theoretically, direct foreign investments which tend to countries that has lack of savings have contributed to solution of saving gap problem or capital accumulation. On the other hand, the direction of direct foreign capital currents will be to countries that have high growth performance, economic and political stability.

In this study, relation between direct foreign investments and economic growth had been searched for 11 APEC Member Countries with the help of panel data analysis by using annual data between 1990 and 2016. In study, whether there are variables or not had been determined by firstly making unit root tests. According to unit root tests, it had been observed that all of taken variables became stable at first difference, in other words variables that are used in analysis did not have unit root. Since taken variables are stable at first difference, whether they are cointegrated or not should be analysed to prevent fake causality relation. With this purpose, Johansen fisher Panel Cointegration Test and Kao Cointegration Test had been applied to determine whether variables are cointegrated or not in equations which are composed for causality tests. Two different test results which are applied as cointegration test have shown that economic growth, capital and direct foreign investment variables move as integrated and there is long-term relation between variables.

While any causality was not determined from economic growth to direct foreign investments for panel set in committed Dumitrescu and Hurlin (2012) panel Granger causality analysis, a Granger causality relation has been seen from direct foreign investments to economic growth.

Although direct foreign investment in most of the developing countries is not directly linked to economic development, capital, technology and knowledge transfer which indirectly contributes. For this reason, developing countries are encouraging foreign direct investment.

\section{REFERENCES}

Ayaydın, H. (2010). Doğrudan yabancı yatırımlar ile ekonomik büyüme arasındaki ilişkinin incelenmesi: Türkiye örneği. Dumlupınar Üniversitesi Sosyal Bilimler Dergisi, 26 (1), ss.133-145.

Alfaro, L., Charlton, A. (2007). Growth and the quality of foreign direct invesment equal?. Working Paper. Harward University.

Blomstorm, M., Lipsey, A. R., Zejan, M. (1992). What explains developing country growth?. NBER Working Paper, No.4132.

Bozuklu, Ş., Yılancı, V. (2013). Finansal gelişme ve iktisadi büyüme arasındaki nedensellik ilişkisi: gelişmekte olan ekonomiler için analiz. Dokuz Eylül Üniversitesi İktisadi ve İdari Bilimler Fakültesi Dergisi Cilt:28, Sayı: 2, Yıl:2013, ss.161-187.

Carcovic, M., Levine, R. (2002). Does foreign direct ınvestment accelerate economic growth? financial globalization: a blessing or curse. World Bank Conference Washinghton.

Choi, I. (2001). Unit root tests for panel data. Journal of International Money and Finance 20 (2001), pp. $249-272$. 
Çeştepe, H., Mıstaçoğlu, T. (2010). Gelişmekte olan ülkelerde doğrudan yabancı yatırımlar ve ekonomik entegrasyon: ASEAN ve MERCOSUR örneği. Yönetim ve Ekonomi, Cilt:17, Sayı:2.

Dumitrescu, E. I., Hurlin, C. (2012). Testing for granger non-causality in heterogeneous panels. Economic Modelling, 29(4), $1450-1460$.

Ekinci, A. (2011). Doğrudan yabancı yatırımların ekonomik büyüme ve istihdama etkisi: türkiye uygulaması (1980-2010). Eskişehir Osmangazi Üniversitesi iliBF Dergisi, 6 (2), ss.71-76.

Im, K. S., Pesaran, H. M., Yongcheol, S. (2013). Testing for unit roots in heterogeneous panels. Journal of Econometrics, c.115, s.53-74.

Işık, C. (2016). Doğrudan yabancı sermaye yatırımları ve ekonomik büyüme ilişkisi: sınır testi yaklaşımıyla Türkiye örneği. IUJEAS, Vol. 1, Issue 1, January 2016.

Kahveci, Ş., Terzi, H. (2017). Türkiye'de doğrudan yabancı yatırımlar ve ekonomik büyüme arasındaki ilişkilerin nedensellik analizleri ile testi. Erciyes Üniversitesi İktisadi ve İdari Bilimler Fakültesi Dergisi, Sayı:49, Ocak-Haziran, ss. 135-154.

Kao, C. (1999). Spurious regression and residual-based tests for cointegration in panel data. Journal of Econometrics 90 (1999), pp.1-44.

Karagöz, K. (2007). Bir sosyal politika aracı olarak doğrudan yabancı yatırımların istihdama etkisi. Sosyoloji Konferansları Dergisi, 36, ss.99114.

Kholdy, S., Ahmad, S. (2005). Financial market, FDI and economic growth: granger causality tests in panel data model. Working Paper, California State Polytechnic University.

Koyuncu, T. F. (2011). Doğrudan yabancı yatırımların iktisadi büyüme etkisi: Türkiye için bir ekonometrik analiz. Paper Presenteol at Econ Anadolu, ss. 1-15.

Levin, A., Lin, C. F., Chia-Shang, Chu, J. (2002). Unit root tests in panel data: asymptotic and finite-sample properties. Journal of Econometrics, v.108, p.1-24.

Maddala, G. S., Wu, S. (1999). A comparative study of unit root tests with panel data and a new simple test. Oxford Bulletin of Economics and Statistics, Special Issue 0305-9049.

Okuyan, H. A., E. E. (2007). Gelişmekte olan ülkelerde doğrudan yabancı yatırımlar ve ekonomik büyüme ilişkisi. Ekonomik Yaklaşım, 19(67), 47-58.

Shaikh, F. M. (2010). Causality relationship between foreign direct investment, trade and economic growth in Pakistan. In International Business Research (Vol. 1, pp. 11-18). Harvard Business School.

Sichei, M., Kinyondo, G. (2012). Determinants of foreign direct Investment in Africa: a panel data analysis. Global Journal of Management and Business Research, 12(18), 85-97.

Şahin, D. (2015). Türkiye'de doğrudan yabancı sermaye yatırımları ve ekonomik büyüme ilişkisi: ARDL sınır testi yaklaşımı. Akademik Sosyal Araştırmalar Dergisi, Yıl: 3, Sayı: 19, Aralık2015, s. 159-172.

Wang, M., Sunny, W. M. C. (2009). Foreign direct investment and economic growth: the growth accounting perspective. Economic Inquiry, 47 (4), pp. 701-710.

Yapraklı, S. (2006). Türkiye'de doğrudan yabancı yatırımların ekonomik belirleyicileri üzerine ekonometrik bir analiz. Dokuz Eylül Üniversitesi i.i..B.F. Dergisi, 2 (2), 23-48.

Yılmaz, Ö., Vedat, K., Akıncı, M. (2011). Türkiye'de doğrudan yabancı yatırımlar ve ekonomik büyümeye etkisi (1980-2008). Atatürk Üniversitesi İktisadi ve İdari Bilimler Dergisi, 25(3-4), 13-30.

Zhang, K. H. (2001). How does foreign direct investment affect economic growth in China?. Economics of Transition, 9 (3), pp. 679-693.

https://www.apec.org/, Erişim Tarihi: 20.03.2018. 